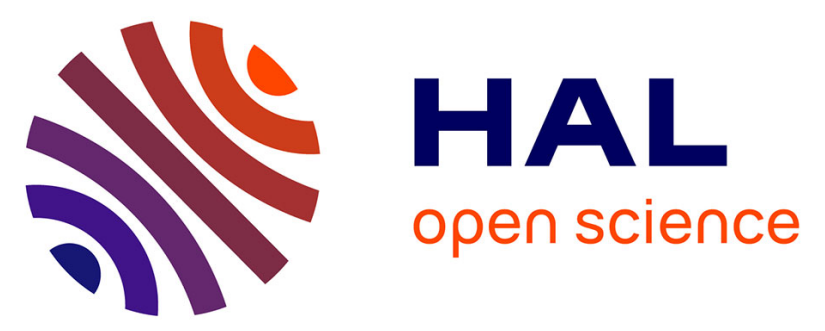

\title{
The use of sentinel logs to assess host shifts in early beetle colonisers of deadwood under climate-and forestry-induced tree species substitutions
}

\author{
Christophe Bouget, Antoine Brin, Laurent Larrieu
}

\section{To cite this version:}

Christophe Bouget, Antoine Brin, Laurent Larrieu. The use of sentinel logs to assess host shifts in early beetle colonisers of deadwood under climate-and forestry-induced tree species substitutions. Insect conservation and diversity, 2021, 14 (1), pp.117-131. 10.1111/icad.12434 . hal-02918315

\section{HAL Id: hal-02918315 \\ https://hal.inrae.fr/hal-02918315}

Submitted on 20 Aug 2020

HAL is a multi-disciplinary open access archive for the deposit and dissemination of scientific research documents, whether they are published or not. The documents may come from teaching and research institutions in France or abroad, or from public or private research centers.
L'archive ouverte pluridisciplinaire HAL, est destinée au dépôt et à la diffusion de documents scientifiques de niveau recherche, publiés ou non, émanant des établissements d'enseignement et de recherche français ou étrangers, des laboratoires publics ou privés. 


\title{
The use of sentinel logs to assess host shifts in early beetle colonisers of deadwood under climate- and forestry-induced tree species substitutions
}

\author{
CHRISTOPHE BOUGET, ${ }^{1}$ ANTOINE BRIN ${ }^{2}$ and LAURENT LARRIEU ${ }^{2,3}{ }^{1}$ INRAE, \\ UR EFNO, Nogent-sur-Vernisson, France, ${ }^{2}$ Université de Toulouse, INRAE, UMR DYNAFOR, Castanet-Tolosan, France and ${ }^{3} \mathrm{CRPF}-$ \\ Occitanie, antenne de Tarbes, Tarbes, France
}

\begin{abstract}
Global change scenarios project drastic modifications in tree species range and an increase in exotic tree plantations. Subsequent tree species substitutions may alter habitat conditions for biodiversity.

2. We measured substitutability between tree species for early deadwood colonisers, through a sentinel log approach, i.e. through the experimental exposure of paired down deadwood (DDW) pieces to native beetles in native stands. We compared two native/ substitute tree species pairs: one conifer pair composed of a rapidly expanding exotic species (Douglas fir) and a declining native species (silver fir), and one deciduous pair composed of two native species, one expanding (sessile oak) and one retreating (beech) at the regional scale.

3. The effects of expanding exotic and native trees on beetle communities were not in line with expectations.

4. Species assemblages in Douglas fir DDW were indistinguishable from those in native silver fir DDW and did not contain fewer species. Assemblages were not more generalist on average in substitutes than in substituted trees: we did not note any decrease in species richness of functional groups to the detriment of specialist species.

5. Moreover, species richness and abundance were higher in substitute oak than in native beech DDW, confirming that species from the regional pool were able to colonise oak, even though it is a minor tree species at the regional level.

6. Large-scale monitoring schemes including multi-taxon, multi-year and multiple native/substitute pairs would further our knowledge of the generic effects of tree species substitution on biodiversity and ecosystem functioning.
\end{abstract}

Key words. Beech, climate change, Douglas fir, exotic plantations, functional trait, oak, saproxylic beetles, Silver fir.

\section{Introduction}

Climate change is expected to greatly affect species distributions in the near future (Thuiller et al., 2005). Throughout Europe, some native tree species are likely to lose climatically favourable areas, and ecoclimatic modelling predicts shrinking distribution areas for some tree species in French forests (Badeau et al., 2010). Climate change scenarios project drastic reductions in

Correspondence: Bouget Christophe, INRAE, UR EFNO, Domaine des Barres, 45290 Nogent-sur-Vernisson, France. E-mail: christophe. bouget@inrae.fr the range of several common species such as European beech (Fagus sylvatica) and silver fir (Abies alba), especially at lower altitudes (Badeau et al., 2010). Over the last 20 years, silver fir (Gillmann et al., 2014) and beech forests (Chira et al., 2003) have already experienced successive dieback episodes in Western and Central Europe.

Meanwhile during the last decades, partly in response to the challenges associated with climate change, forest managers throughout the world have increasingly been planting exotic tree species in their search for commercial tree species that are better adapted to future climatic conditions (Canadell \& Raupach 2008). As examples, Douglas fir (Pseudotsuga menziesii) and 
Atlas cedar (Cedrus atlantica) have increasingly been promoted in western European forestry in place of native conifers (Schmid et al., 2014) because of their resistance to drought, their yield and their wood quality.

These changes in native tree species' ranges due to both the influence of climate change and the forestry-induced expansion of exotic tree species are likely to alter habitat conditions for forest biodiversity (Felton et al., 2013), example through the tree species composition of dead wood available for saproxylic biodiversity (Ulyshen et al., 2018). The composition of dead wood in terms of host tree species is a fundamental dimension of food suitability and resource availability for saproxylic taxa (e.g. Bouget et al., 2013; Müller et al., 2015). However, host tree specificity among saproxylic species is not so narrow: for instance, $75 \%$ of French saproxylic beetle species for which data are readily available, are not specific to a single host species but are known to use at least two tree species (Bouget et al., 2019)!

There is an emerging body of literature on the response patterns of wood-associated organisms to tree species substitution, including phytophagous (eg Brändle et al., 2008) or xylophagous insects (e.g. Zumr, 1992, Bertheau et al., 2009) and more rarely, fungi (Gange et al., 2011; Heilmann-Clausen \& Læssøe, 2012). The colonisation of exotic tree deadwood by native xylophagous insects remains poorly known and available studies have given contrasted results (see review by Ulyshen et al., 2018). Several ecological mechanisms inherent to the new host trees (regional abundance, presence of congeneric native trees, time elapsed since introduction) or to the insects themselves (host tree diversity), may be involved in the occupancy of exotic trees by native insects (Gossner et al., 2009). Colonisation of new host trees concerns both local shifts in species associated to the substituted tree species, and the contribution of the regional pool of species. Several ecological hypotheses have been invoked to explain the community assembly of native insect species found on new host trees. Some concepts focus mostly on herbivores and living trees, and cannot be extended to deadwood eaters. For instance, the Biotic Resistance Hypothesis stipulates that introduced tree species recognised as a food source by native herbivores are less well defended than native trees due to a lack of coevolution (Lombardero et al., 2012); introduced species are therefore more easily colonised by native herbivores than are native substrates. Conversely, other concepts relevantly apply to dead wood substrates. On the one hand, the ecological concept of "escape in space from enemies" (Brin \& Bouget, 2018) stems from the idea that wood-dwelling insects and their natural enemies exhibit contrasting colonisation abilities when the resource is highly aggregated in space and time. Even though wood-feeding beetles are more demanding in terms of host tree species than zoophagous beetles, they may benefit from decreased predation pressure in new resource patches, which are more slowly colonised by predator species. On the other hand, biotic homogenisation may occur; this refers to the occupancy of exotic substrates by widespread generalist species to the detriment of native specialist biotas in changing, especially human-altered, environments (McKinney \& Lockwood, 1999; Smart et al., 2006). The direct and indirect consequences of tree species substitutions on biodiversity are of interest not only in terms of conservation strategies for endangered species (Mori et al., 2017), in particular saproxylic species, but also in terms of ecosystem functioning (e.g. deadwood decomposition or biotic regulation of pathogens and pests).

In an experiment in natural conditions, we measured the substitutability between two tree species (one substitute and one substituted) for early deadwood colonisers using a 'sentinel log' method, i.e. through the experimental exposure of paired down deadwood (DDW) pieces to native beetles in native stands. Our 'sentinel log' approach was symmetrically derived from the 'sentinel plant' method, which is increasingly advocated as a strategy to identify potential plant pests in a particular region before they are introduced (Mansfield et al., 2019).

Herein, we document the early colonisation of freshly cut deadwood by saproxylic beetles, which is likely to precondition the deadwood for further succession by other invertebrates and fungi (Stokland et al., 2012). Saproxylic beetle assemblages are composed of interacting guilds, including mainly xylophagous wood-borers, consumers of wood-decaying fungi and predators (Bouget et al., 2019). Assemblage dissimilarity between tree species is assumed to be particularly significant for pioneer xylophagous species, known to be more closely associated to tree species or tree genus than other feeding guilds (Dajoz, 2000). The colonisation of an introduced tree species substrate through insects from the regional species pool breeding on the substituted tree species could therefore be partial. We hypothesised that species richness for early deadwood colonisers would be lower in DDW from the substitute tree species than in DDW from the substituted tree species. According to the ecological hypotheses mentioned above, we also expected contrasts in species assemblage composition in the DDW between the substitute and the substituted tree species, to the detriment of specialist or zoophagous species and in favour of generalist species in the substitute tree deadwood.

\section{Materials and methods}

\section{Experimental design}

To focus on the effects of wood quality and discard potential effects of local deadwood quantity and diversity on insect diversity associated with native and non-native trees, we used emergence traps to collect insects directly from woody substrates organised in a paired design. Two pairs of tree species (one substitute and one substituted) were compared to reveal distinct patterns of tree species substitution. The conifer pair was composed of an exotic species, Douglas fir (Pseudotsuga menziesii), which is being increasingly planted as a substitute for a native species, silver fir (Abies alba), currently decreasing in surface area, mainly at low elevations. The deciduous pair included a native species expanding in range due to its low sensitivity to climate change, sessile oak (Quercus petraea), as a substitute for European beech (Fagus sylvatica), a native species whose range is shrinking (Badeau et al., 2010). Fresh woodfrom these four tree species was sawn off trees felled during winter 2015-2016. Two diameter classes were collected: 1-m-long small branches $(2.5-7.5 \mathrm{~cm}$ in diameter; $n=400)$ and 1 -m-long logs $(7.5-12.5 \mathrm{~cm}$ in diameter; $n=160)$, making 100 branches 
and $40 \operatorname{logs}$ for each tree species. The 'Sentinel logs', bundles made up of this artificially created Down Deadwod (DDW), were exposed to colonisation by native beetles from March to October 2016 in two different regions depending on the tree species: (i) for the Douglas fir/silver fir pair - in the Pays de Sault (Eastern Pyrenees, $1000 \mathrm{~m}$ asl, $n=10$ plots) and Baronnies (Central Pyrenees, 800-1200 m asl, $n=10$ plots), and (ii) for the sessile oak/beech pair - in the Eawy forest (Normandy, $200 \mathrm{~m}$ asl, $n=10$ plots) and Baronnies (Central Pyrenees, $800-1200 \mathrm{~m}$ asl, $n=10$ plots) (see map in Fig. 1). The plots were selected in stands dominated by the native substituted tree species (in a 300 m-radius buffer zone) and surrounded by forests where the substituted tree species is very common at the landscape scale (3000 ha). The substitute tree species was absent from the experimental stand and the $300 \mathrm{~m}$-radius buffer zone, and rare at the landscape scale. This sampling design simulated a change in tree species dominance and avoided situations where the substitute tree species was already quite common. The plots were set up in mature stands (i.e. more than 100 years old) and recently harvested or windthrown areas ( $<2$ years) were excluded. The minimum distance between plots was $300 \mathrm{~m}$ and they were located more than $30 \mathrm{~m}$ from the forest edge. Each plot was divided into two subplots, $5 \mathrm{~m}$ far away from each other. In each subplot, one bundle with one $\log$ and two (or three) branches of the substitute tree species and one bundle with one log and two (or three) branches of the substituted tree species were placed $50 \mathrm{~cm}$ apart on the ground, in an area deprived of bushy vegetation. Overall, the experimental design was balanced in terms of diameter class and tree species replicates.

\section{Sampling early wood colonisers}

The experimental DDW was collected at the end of the active flying season for insects (October) and immediately put into

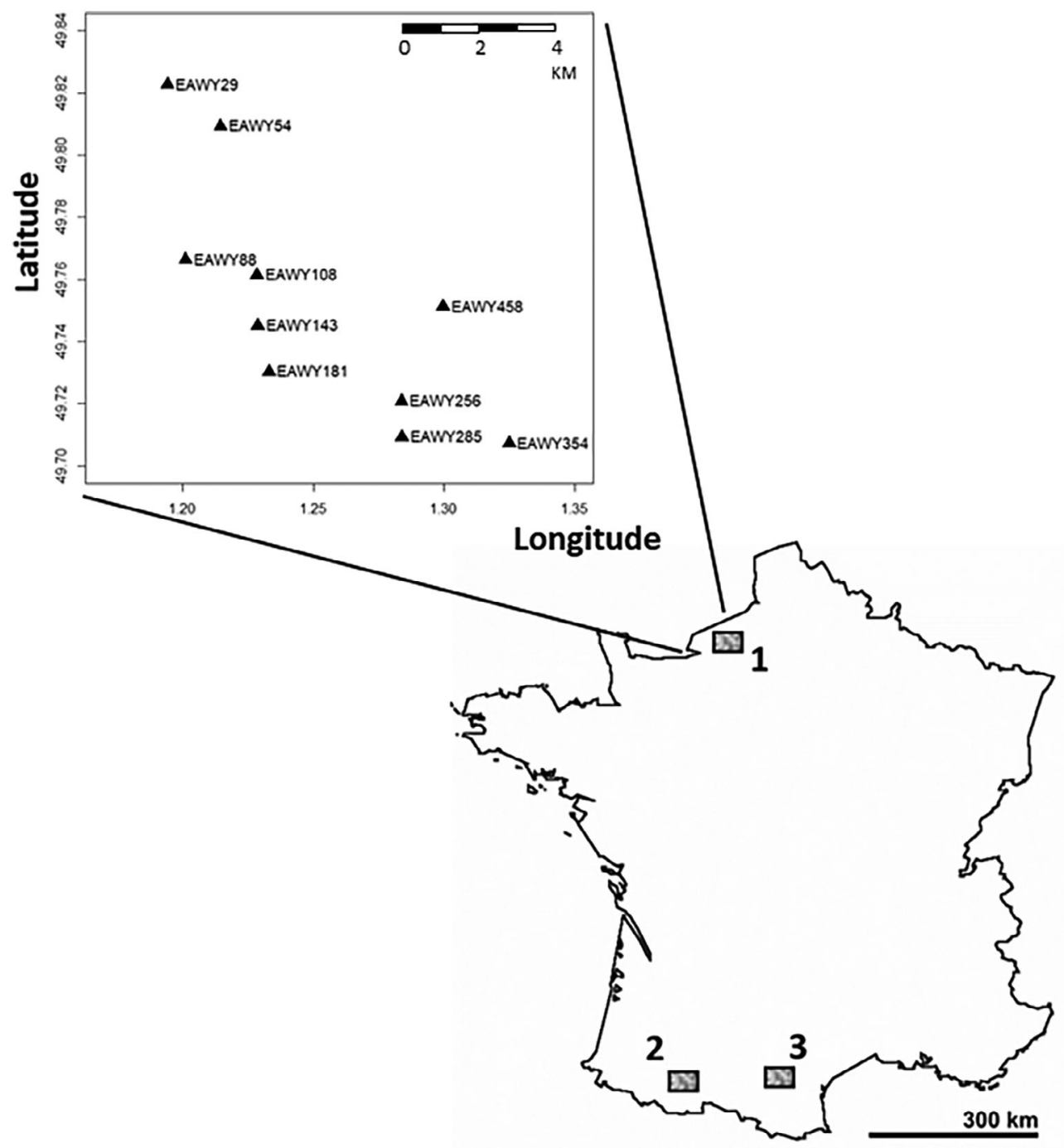

Figure 1. Map of the distribution of study sites: (1) Eawy forest, (2) Baronnies forests, (3) Pays de Sault, and zoom in on the spatial design of 10 plots in the Eawy fores

(C) 2020 The Royal Entomological Society, Insect Conservation and Diversity, doi: 10.1111/icad.12434 
emergence bags. We used one bag per plot, per tree species and per log type, which meant that each bag contained either two deadwood logs or five deadwood branches according to their diameter class. The 160 emergence bags were left under natural forest conditions and monitored. Their collectors were regularly emptied to sample the emerging beetles over 18 months starting in April 2017, since most beetle colonisers have a 1-year development cycle. The beetles were identified at the species level whenever possible; 20 taxa were identified at the genus level only.

Beetle species traits. We selected two crucial ecological traits related to the ecological requirements of each species: (i) feeding habit and (ii) host tree preference. The trait values were extracted from the ecological information stored in the French database on saproxylic beetle ecology (Bouget et al., 2019; Table A2). Two feeding guilds, wood-eating species (including both xylophagous and saproxylophagous beetles) and lignicolous zoophagous species, were assessed. The response of the mycophagous beetle guild, poorly represented in our current data, was not analysed. Host tree preference was encoded by an index value as follows: (i) oligophagous species associated with a few deciduous tree species at most, or oak specialists; (ii) species associated with deciduous trees in general; (ii) polyphagous generalists associated with both coniferous and decidous trees; (iv) species associated with conifersin general; and (5) oligophagous species associated with a few conifers at most, or fir specialists.

\section{Data analysis}

All analyses were performed in $\mathrm{R}$, version 3.5.1 ( $\mathrm{R}$ Core Team 2018). The beetle data from the emergence bags were merged for each diameter class and each tree species.

To describe beetle assemblage structure, we computed community-weighted means (CWM) and functional dispersion (FDis) for host tree preference values (dbFD function, FD package, Laliberté \& Legendre, 2010). CWM is defined as the mean of trait values weighted by the relative abundance of each species bearing each value. FDis is defined as the mean distance of a given individual species to the weighted centroid of all the species in the assemblage and is unaffected by species richness (Laliberté \& Legendre, 2010). An increase in CWM of the host tree preference trait corresponds to a more generalist species assemblage in deciduous case studies (i.e. polyphagous on average), but to a more specialist species assemblage in coniferous plots (fir specialists). In coniferous and deciduous case studies, an increase in trait FDis indicates a more generalist species assemblage.

To determine whether and how univariate assemblage metrics were influenced by tree species, we computed either linear or generalised linear mixed models. We investigated the following response variables: mean values per trap of CWM or FDis for host tree preference, number of individuals and species for all species and feeding guilds, and the abundance ratio of wood-eating/zoophagous. The error structure of the generalised linear mixed-effects models was adjusted to better fit the data. To do

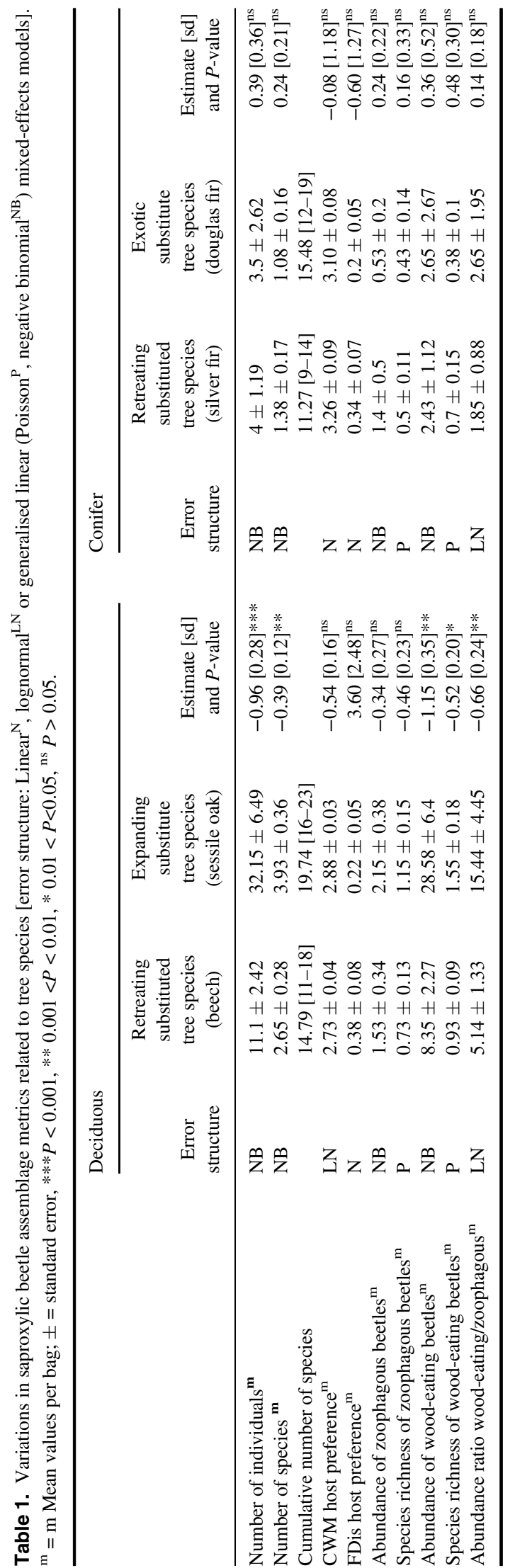

(C) 2020 The Royal Entomological Society, Insect Conservation and Diversity, doi: 10.1111/icad.12434 
so, glmms were fitted for the negative binomial family, the lognormal family (i.e. log-transformed response), the Poisson family (glmer.nb, glmer, lmer, lme4 functions, R-package), with region and plot as nested random effects accounting for the spatial configuration of the sampling design, and with diameter class as a secondary covariate accounting for the differences between branches and logs.

A species accumulation function (rich R-package) computed rarefaction curves and returned the bootstrap estimate of cumulative species richness for each tree species, for a standard interpolated number of sampled sites ( $n=20$ samples for coniferous tree species; $n=30$ samples for deciduous tree species, 1000 random permutations), as well as its statistical envelope (lower and upper bounds of the estimate corresponding to the quantile values at a $P$-value $=5 \%$.

To determine whether the species composition of the saproxylic beetle assemblages was influenced by tree species, we performed PERMANOVA analyses (Anderson \& Walsh, 2013) based on a Bray-Curtis distance, with 999 permutations constrained by study region (vegan package). We used the $\mathrm{R}$ function nestedbetasor (vegan package) to partition the Sorensen dissimilarity index into: (i) the Simpson dissimilarity index, describing spatial turnover (where some species are replaced by others as a consequence of environmental sorting or spatial and historical constraints), and (ii) the nestednessresultant dissimilarity (where the species from samples with lower species richness are subsets of the species in richer samples, reflecting a non-random process of species loss) (Baselga, 2012).

To investigate the preferences of individual beetle species for tree species, we used indicator species analysis (multipatt function, indicspecies package, De Cáceres \& Legendre, 2009) based on the indicator value index (IndVal) to combine the exclusivity and fidelity of species within a group of sites. Low-frequency (occupied sites $<10 \%$ ) and low-abundance species ( $<10$ individuals in total) were discarded. We therefore included only seven beetle species for the beech-oak pair and six species for the silver fir-Douglas fir pair in the analysed table. Permutation tests $(n=9999)$ assessed the statistical significance of the indicatorspecies values.

\section{Results}

Overall, the experimental DDW was successfully colonised during the experiment, since only a few emergence bags $(7 \%$ of the log bags and $18 \%$ of the branch bags) did not provide any beetles during the 18-month period. The proportion of empty bags (i.e. without any emerging beetles) depended on tree species: $20 \%$ for Douglas fir, $14 \%$ for silver fir, 9\% for beech and $8 \%$ for sessile oak. Tree species did not significantly affect the mean number of empty bags per plot (see
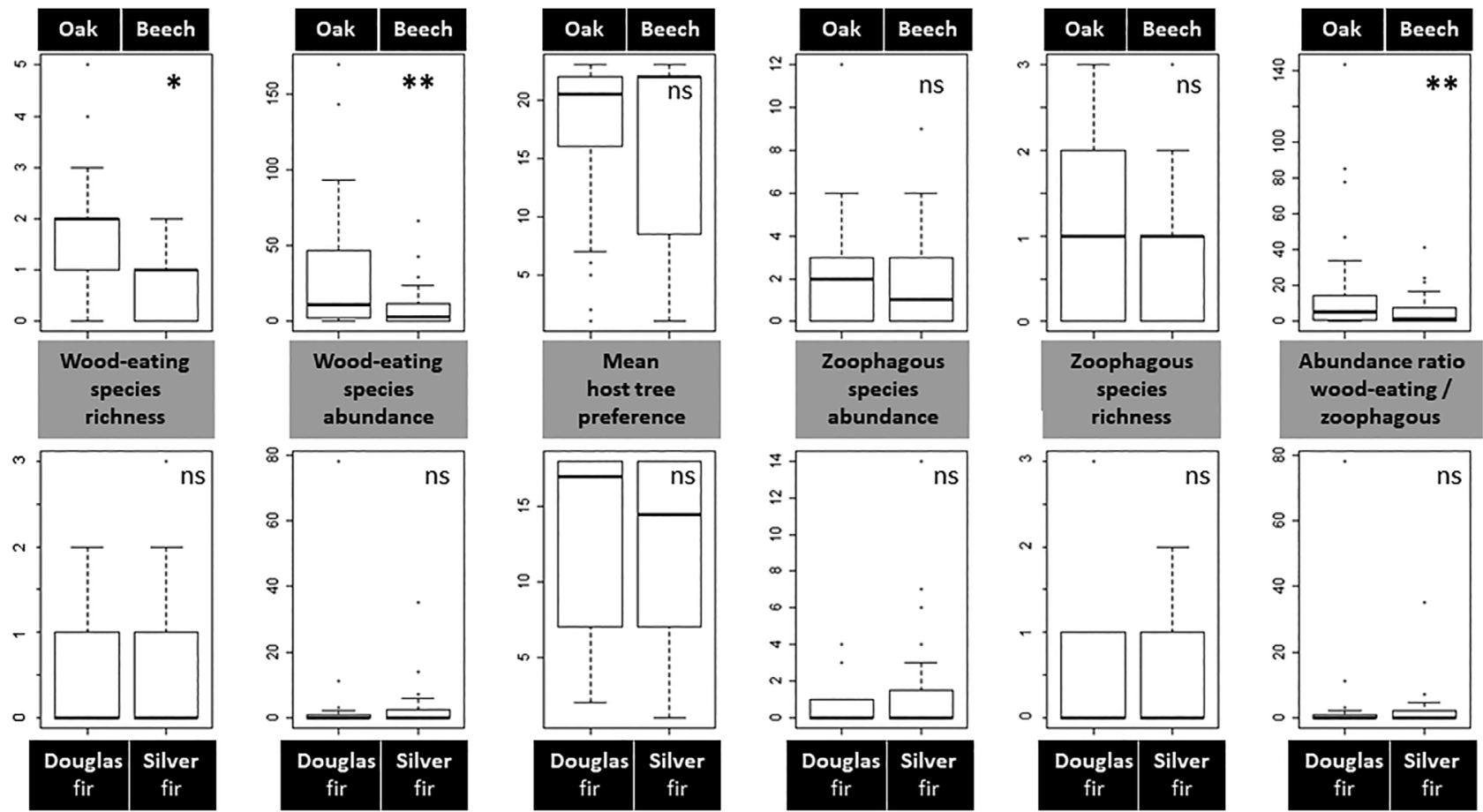

Figure 2. Effect of tree species on saproxylic beetle assemblage metrics (mean host tree preference, mean abundance and species richness for all species and feeding guilds, abundance ratio of wood-eating/zoophagous beetles) in paired comparisons (substitute vs substituted, deciduous above, conifer below) using linear or generalised linear mixed models. An increase in CWM of the host tree preference trait (mean host tree preference) corresponds to a more generalist species assemblage in deciduous case studies (i.e. polyphagous on average), but to a more specialist species assemblage in coniferous plots (fir specialists). See table 1 for error structure and detailed statistical results for each response variable, $* * * P<0.001 ; * * 0.001<P<0.01,{ }^{*} 0.01<P<0.05$, ns $P>0.05$ 
Table A1. The whole sampling design provided 1885 saproxylic beetle individuals in 53 taxa (including 24 singletons, see Table A2).

Mean numbers of saproxylic beetle individuals and species per bag were similar for both conifers, but significantly higher for oak than for beech (Table 1). The cumulative number of species was on average more than $30 \%$ higher in the DDW of the substitute tree species than in the substituted tree species, for both coniferous and deciduous species pairs (Table 1), even though bootstrap confidence intervals slightly overlapped in each pair.

PERMANOVA analyses of differences in species composition showed a slightly significant contrast between beech and sessile oak ( $P=0.01,1000$ replications), but a non-significant assemblage dissimilarity between Douglas fir and silver fir ( $P=0.07,1000$ replications). In the beech-oak case study, the contribution of nestedness to total dissimilarity was very low (2.8\%), while spatial turnover processes were dominant $(97.2 \%)$.

Paired comparisons of assemblage metrics between tree species revealed not very many significant differences. No difference in the CWM or FDis of the host preference trait was measured between substituted and substitute tree species, either for broadleaves or for conifers (Table 1). For the deciduous species, more wood-eating beetle species and individuals were caught on average per bag from oak than from beech deadwood (Table 1; Fig. 2); mean abundance ratio (wood-eating/zoophagous) was significantly higher in oak than in beech deadwood (Fig. 2). In the coniferous context, a similar number of woodeating individuals and species emerged from silver fir and from Douglas fir deadwood (Fig. 2). Mean numbers of zoophagous beetles and mean abundance ratio [wood-eating/ zoophagous] were also similar for both Douglas and Silver fir (Table 1; Fig. 2).

From mixed models focusing on univariate assemblage metrics, only consistent results across the two study regions were retained. It should however be noted that some regional discrepancies occurred when comparing substituted and substitute tree species. The contrast was actually stronger in Eawy than in Baronnies site for broadleaves, and in Sault than in Baronnies site for conifers (Table A3).

From the IndVal analysis conducted on a small number of selected species, one species was significantly characteristic of beech deadwood (Cartodere nodifer, Latridiidae, $P<0.05$ ); another one was associated to silver fir deadwood (Pissodes piceae, Curculionidae, $P<0.05$ ); and two species were specific to oak deadwood (Xylosandrus germanus, Curculionidae, and Rhizophagus bipustulatus, Monotomidae). Finally, only two nationally listed rare species were detected in our dataset: $K y k$ lioacalles pyrenaeus (Curculionidae), caught in both silver and Douglas fir deadwood, and Laemophloeus kraussi (Laemophloeidae), which emerged from beech wood.

\section{Discussion}

The success of our emergence experiment in data provision compared with other published studies (e.g. Nittérus et al. 2004; Della Rocca et al., 2016) should be noted. Overall, though we focused on small-diameter classes and early decay stages, we measured only a slight response of saproxylic species to tree substitution. We did not observe sharply distinct wood-dwelling beetle assemblages in the fresh deadwood from the substitute tree species compared with the native substituted tree species. Moreover, the highest dissimilarity level we observed was between the two deciduous native species, not between the exotic and native coniferous species.

In the conifer case study (native vs exotic), deadwood from the exotic Douglas fir did not provide fewer species on average per deadwood piece. On the contrary, Douglas fir deadwood held more total species over the sampling design, in line with the Biotic Resistance Hypothesis suggested for herbivores (Lombardero et al., 2012). Overall species composition was not distinct and not nested between exotic Douglas fir and native Silver fir. Indeed, species assemblages in Douglas fir deadwood did not contain a smaller number of species. About $50 \%$ of the taxa collected from Douglas fir substrates were listed for Silver fir deadwood in the French database on saproxylic beetle ecology (Bouget et al., 2019). It is noteworthy that Douglas fir is listed as a potential host tree species for only 12 out of the 260 conifer-preferring xylophagous beetle species in the French database on saproxylic beetle ecology (Bouget et al., 2019). Overall, improved knowledge of the niche breadth of woodassociated insects would be informative.

Mean values and dispersion of quantitative traits were not lower in Douglas fir than in silver fir deadwood, which means that assemblages were not more generalist on average in substitute than in substituted trees. In other words, no sign of biotic homogenisation of fresh-deawood beetle coloniser assemblages was detected on Douglas-fir. Müller et al. (2015), but also Roques et al. (2006), insisted on the lack of specialist species among the species colonising Douglas fir; they represented only a small generalist subset of the assemblage collected from native spruce. In the available literature, the reported ecological impacts of Douglas fir plantations on biodiversity are diverse and often inconsistent (Tschopp et al., 2015); in general, the impacts are considered less severe than those of other exotic tree species (Schmid et al., 2014). In line with our results, a previous study found that the number of species in arthropod communities on Douglas fir was similar to the one on native conifer species (Schmid et al., 2014). Another study restricted to scolytids colonising experimentally exposed deadwood found no difference in species richness among native conifers [namely Norway spruce (Picea abies), Scots pine (Pinus sylvestris), Silver fir and Douglas fir] (Bertheau et al., 2009). In the European study by Branco et al. (2015), Douglas fir was the exotic species that recruited the greatest number of native insects. Contrary to our results, Müller et al. (2015) clearly demonstrated that saproxylic beetles avoided experimental logs of exotic Douglas fir DDW in Germany, in accordance with another German study of saproxylic canopy arthropods (Gossner \& Ammer, 2006). It should be pointed out that their set of experimental logs included mainly large deadwood pieces, $20-60 \mathrm{~cm}$ in diameter, which makes their design clearly different from ours. Knowing that contrasts in bark thickness between Silver and Douglas fir mainly occur in large-diameter logs, sampling gaps may contribute to the observed discrepancies in beetle response. 
Tree-associated insects would appear to colonise new woody resources, such as the exotic deadwood in our study, more easily and more quickly than do their natural enemies ("escape in space from enemies", Brin \& Bouget, 2018). Such a shift in arthropod communities is nevertheless still controversial, since Hartley et al. (2010) found lower herbivore abundance but more predator species on a recently introduced exotic tree species compared to the native species. In our results, at odds with the "escape" hypothesis, indigenous predators used the exotic DDW as foraging habitat, so that zoophagous species richness and abundance, and relative number of zoophagous individuals compared to xylophagous prey, were equal in Douglas fir DDW and in silver fir DDW. Consequently, no decrease in potential pest regulation by natural enemies was observed in exotic DDW compared with the native DDW.

Factors other than a lack of natural enemies can facilitate or constrain establishment success of indigenous insects on a new host such as Douglas fir in Europe (Neuvonen \& Niemela, 1981). The probability of exotic trees being colonised by native insects increases with (i) the presence of congeneric native trees in the area of introduction or the close phylogenetic proximity with native tree species (Connor et al., 1980); (ii) the abundance and geographical extent of forests planted with exotic trees (Branco et al., 2015); and (iii) the time elapsed since introduction (Brändle et al., 2008). Although Douglas fir has no congeners in Europe, it was first introduced to France from North America more than 175 years ago and it has been planted on a large scale in European forests for 50 years (Schmid et al., 2014).

So far studies comparing the colonisation of exotic and native trees by native insects have given contrasting results (Ulyshen et al., 2018), partly due to differences in substrate features (size, decay) involved in the comparisons. Newly introduced conifers are often more colonised than native species but opposite conclusions have been reported as well, both in temperate and Mediterranean forests (Evans, 1987; Fraser \& Lawton, 2008; see also Lachat et al., 2007 in tropical forests). In European Nordic countries, among the 80 insect species observed reproducing on the introduced lodgepole pine (Pinus contorta, Engelmark et al., 2001), the majority use native Scots pine as their main host. Some pine-associated species are missing on lodgepole pine, partly due to different bark structure. Contrary to expectations, most of the insect species that have colonised the suboptimal lodgepole pine hosts are Scots pine specialists rather than generalists (with regard to host selectivity; Lindelöw \& Björkman, 2001). Historical factors seem to play a crucial role in the recruitment of specialist insects (Dalin \& Björkman, 2008). Buse et al. (2010) and Degomez and Wagner (2001) also found far lower numbers of saproxylic beetles or arthropods on two non-native trees (Pinus brutia in Israel and Robinia pseudoacacia in Arizona, respectively), both of which had been introduced into the study region approximately 100 years before. Similarly, Eucalyptus, introduced into southern Europe in the middle of the 19th century, can only be utilised by a relatively small number of insect species with generalist host preferences, as shown in a study in Spain (Lombardero et al., 2012). On the other hand, Della Rocca et al. (2016) observed no differences in saproxylic species composition among exotic (Robinia pseudoacacia, present in Italy for approximately
400 years) and native trees (such as Quercus robur and Populus alba).

One may also consider the consequences of tree species substitutions on biodiversity in terms of ecosystem functioning. Fresh deadwood mainly attracts early colonisers, which are likely to precondition the deadwood for further succession by fungi and other invertebrates (Stokland et al., 2012). For our experimental data, xylophagous species richness and abundance was equal in Douglas fir and silver fir DDW. Despite this stable xylophagous beetle abundance, we cannot definitely exclude a decrease in initial decomposition ability in exotic DDW. Preliminary data on the fungus communities of our experimental logs suggest that Douglas fir hosts lower species richness and distinct species assemblages compared with Silver fir. Given these contrasting responses for two crucial groups in the wood decomposition process, the overall decomposition of exotic DDW should be further investigated. A decomposition experiment by Ulyshen et al. (2018) in the United Sates suggests that termites did not contribute as significantly to the decomposition of non-native wood species as they did for native wood species. Nonetheless, Fierro et al. (2017) assert that the ecosystem services provided by saproxylic beetles are as functional in exotic pine plantations as in native forests.

In our deciduous case study (native expanding vs native retreating), we found a slight but significant dissimilarity in saproxylic species assemblage composition between the two communities associated to the tree species: beech, currently dominant but retreating, and sessile oak, locally minor but potentially expanding at the regional level. Assemblage composition is known to be dissimilar in oak and beech substrates (Kappes \& Topp, 2004). In our study, the beech-oak contrast was stronger in the mountainous Baronnies site than in the lowland Normandy site, even though the occurrence of oak and beech is more sharply spatially segregated in highland contexts. The dissimilarity pattern was mainly due to species turnover and not to nestedness, which means that beech specialists could be losers in case of tree substitution. It should be noted, however, that all the species collected in our samples from deciduous tree substrates had previously been recorded at the national level on both oak and beech deadwood in the French database on saproxylic beetle ecology (Bouget et al. 2019). Bearing this in mind, the between-species dissimilarity patterns we observed may involve distinct biotic interactions on oak or beech substrates, or they may reflect stochastic colonisation processes at a fine-grained scale (Brin \& Bouget, 2018). They may also sometimes relate to indirect colonisation processes mediated by deadwood-associated microhabitats, such as wood-decaying fungi, which occur more frequently on native beech substrates. Our logs and branches were actually colonised by local fungi and partly covered by fungus mats at bagging at the end of the experimental colonisation period (1 year). The beech logs and branches probably hosted more fungi than did the oak deadwood and were consequently more attractive to fungicolous beetles, such as Cartodere nodifer (Latridiidae), a fungus feeder characteristic of beech deadwood from our IndVal results. Our results did not show any biotic homogenisation, nor did we find any decrease in decomposition ability or in pest biotic regulation ability at the assemblage level. The xylophagous functional 
groups even seemed more abundant and more diverse in the substitute tree species. Along the same lines, species richness and abundance were higher in DDW from the substitute tree species, in accordance with the exceptionally high species richness of associated specialist insect herbivore species observed on oaks (Brändle \& Brandl, 2001). Previous faunistic comparisons of various tree species have revealed that oak hosts richer communities than does beech (Bouget et al., 2019); this is also true for fresh logging residues (Lassauce et al., 2012). Our results suggest that species from the regional pool were able to colonise sessile oak deadwood, even when oak is a minor tree species at the local, or forest, level. Oak specialists may have adapted to colonising scattered oak trees in natural lowland beech-oak forests; from Müller et al. (2015), the choice of host trees by local saproxylic beetle communities is not driven by regional resource availability. Given the oak-beech dissimilarity, our findings are not in line with a shift of beech-associated species to oak substrates.

Large sampling schemes should be designed to explore the response of assemblages and individual species to tree substitution and to detect ecosystem function implications and potential loser species among native host-tree specialists. Comprehensive systems should involve (i) the monitoring of sentinel logs and (ii) insect window-flight trapping in exotic forest plantations. They should have a multi-taxon scope, and at least monitor both insect and fungus colonisation. Contrasting colonisation of exotic substrates by insects and fungi has indeed already been demonstrated (Lombardero et al., 2012; Schmid et al., 2014; Ulyshen et al., 2018) and even observed in our context in a companion study comparing Douglas and silver fir (unpublished results). A thorough multi-taxon approach would help to determine whether non-native deadwood does indeed provide valuable habitats from a conservation perspective (Ulyshen et al., 2018). Deadwood monitoring should also encompass a large range of DDW diameters and positions (shaded vs sunny, ground-lying vs standing, etc.) and extend over a long time period (at both the colonisation and emergence steps) to address the effects of tree species substitution on saproxylic species depending on large-diameter, deadwood-associated microhabitats whose occurrence increases with decaying time, and/or rotten logs (Kostanjsek et al., 2018) and should include species with a multi-year development stage. Since we here observed significant between-site discrepancies, the whole experimental design should include many sampling sites. The monitoring should also extend to other native/substitute pairs, including many expanding exotic tree species.

\section{Acknowledgements}

The authors would like to thank Serge Pastore (ONF Eawy), Pierre Miller (ONF Rouen), Jean-Pierre Bazerque (GF des Baronnies) and Gilbert Verdier (GF de Hèches) for providing access to the experimental sites; to Thierry Gautrot (ONF St-Palais), Stéphane Matz (Irstea), Paul-Henry Merle (Society BongardBazot) and Magali Maviel (CRPFO) for their support in collecting the stock of experimental deadwood; to Carl Moliard (Irstea), Benoit Nusillard (Irstea) and Lionel Valladares (EIP) for monitoring the emergence traps and examining the entomological samples; to Hervé Brustel (EIP) for providing a rearing place under forest conditions; to Gilles Corriol for his mycological expertise on the DDW at the Pyrenean sites, Sylvie Ladet for checking the spatial metrics of experimental sites, and Vicki Moore for reviewing the English manuscript. The authors are deeply grateful to two anonymous reviewers whose comments helped them to improve the manuscript. This work was supported by the French ministry in charge of ecology (SAPROCLIM grant, Convention MEEM - DEB 2016-2018, 15/07/2016).

\section{Conflict of interest}

The authors have no known conflicts of interest associated with the publication of this study. The authors certify that there are no disputes over the ownership of the data presented in the paper. All contributions have been attributed appropriately, via coauthorship or acknowledgement, as appropriate to the situation.

\section{Data availability statement}

Data available on request from the authors

\section{References}

Anderson, M.J. \& Walsh, D.C. (2013) PERMANOVA, ANOSIM, and the Mantel test in the face of heterogeneous dispersions: what null hypothesis are you testing? Ecological Monographs, 83, 557-574.

Badeau, V., Dupouey, J.L., Cluzeau, C., Drapier, J. \& Le Bas, C. (2010) Climate change and the biogeography of French tree species: first results and perspectives. Forests, Carbon cycle and Climate Change (ed. by D. Loustau), pp. p. 231-252. Quae, Paris.

Baselga, A. (2012) The relationship between species replacement, dissimilarity derived from nestedness, and nestedness. Global Ecology and Biogeography, 21, 1223-1232.

Bertheau, C., Salle, A., Rossi, J., Bankhead-Dronnet, S., Pineau, X., Roux-Morabito, G. \& Lieutier, F. (2009) Colonisation of native and exotic conifers by indigenous bark beetles (Coleoptera: Scolytinae) in France. Forest Ecology and Management, 258, 1619-1628.

Bouget, C., Brustel, H., Noblecourt, T. \& Zagatti, P. (2019) Les coléoptères saproxyliques de France - Catalogue écologique illustré, Éditions MNHN, Vol. 738. collection Patrimoines Naturels.

Bouget, C., Larrieu, L., Parmain, G. \& Nusillard, B. (2013) In search of the best local habitat drivers for saproxylic beetle diversity in temperate deciduous forests. Biodiversity and Conservation, 22, 2111-2130.

Branco, M., Brockerhoff, E.G., Castagneyrol, B., Orazio, C. \& Jactel, H. (2015) Host range expansion of native insects to exotic trees increases with area of introduction and the presence of congeneric native trees. Journal of Applied Ecology, 52, 69-77.

Brändle, M., Kühn, I., Klotz, S., Belle, C. \& Brandl, R. (2008) Species richness of herbivores on exotic host plants increases with time since introduction of the host. Diversity and Distributions, 14, 905-912.

Brändle, M. \& Brandl, R. (2001) Species richness of insects and mites on trees: expanding Southwood. Journal of Animal Ecology, 70, 491-504.

Brin, A. \& Bouget, C. (2018) Biotic interactions between saproxylic insect species. Saproxylic Insects: Diversity, Ecology and 
Conservation. Zoological Monographs(ed. by M. Ulyshen), Vol. 1, pp. p. 471-514. Springer, Cham.

Buse, J., Levanony, T., Timm, A., Dayan, T. \& Assmann, T. (2010) Saproxylic beetle assemblages in the Mediterranean region: impact of forest management on richness and structure. Forest Ecology and Management, 259, 1376-1384.

Canadell, J.G. \& Raupach, M.R. (2008) Managing forests for climate change mitigation. Science, 320, 1456-1457.

Chira, D., Dănescu, F., Roşu, C., Chira, F., Mihalciuc, V., Surdu, A. \& Nicolescu, V.-N. (2003) Some recent issues regarding the European beech decline in Romania. Annals of Forest Research, 46, 167-176.

Connor, E., Faeth, S., Simberloff, D. \& Opler, P. (1980) Taxonomic isolation and the accumulation of herbivorous insects - a comparison of introduced and native trees. Ecological Entomology, 5, 205-211.

Dajoz, R. (2000) Insects and Forests: The Role and Diversity of Insects in the Forest Environment, Vol. 668. Intercept Lavoisier Publishing, Paris.

Dalin, P. \& Björkman, C. (2008) Native insects colonizing introduced tree species-patterns and potential risks. Invasive Forest Insects, Introduced Forest Trees, and Altered Ecosystems(ed. by $\mathrm{T}$. D. Paine), pp. p. 63-77. Springer, Dordrecht.

De Cáceres, M. \& Legendre, P. (2009) Associations between species and groups of sites: indices and statistical inference. Ecology, 90, 3566-3574.

Degomez, T. \& Wagner, M.R. (2001) Arthropod diversity of exotic vs. native Robinia species in Northern Arizona. Agricultural and Forest Entomology, 3, 19-27.

Della Rocca, F., Stefanelli, S. \& Bogliani, G. (2016) Robinia pseudoacacia as a surrogate for native tree species for saproxylic beetles inhabiting the riparian mixed forests of northern Italy. Agricultural and Forest Entomology, 18(3), 250-259.

Engelmark, O., Sjöberg, K., Andersson, B., Rosvall, O., Ågren, G.I., Baker, W.L., Barklund, P., Björkman, C., Despain, D.G., Elfving, B., Ennos, R.A., Karlman, M., Knecht, M.F., Knight, D.H., Ledgard, N.J., Lindelöw, A., Nilsson, C., Peterken, G.F., Sörlin, S. \& Sykes, M.T. (2001) Ecological effects and management aspects of an exotic tree species; the case of Lodgepole pine in Sweden. Forest Ecology and Management, 141, 3-13.

Evans, H. (1987) Sitka spruce insects: past, present and future. Proceedings of the Royal Society of Edinburgh. Section B. Biological Sciences, 93, 157-167.

Felton, A., Boberg, J., Björkman, C. \& Widenfalk, O. (2013) Identifying and managing the ecological risks of using introduced tree species in Sweden's production forestry. Forest Ecology and Management, 307(1), 165-177.

Fierro, A., Grez, A., Vergara, P.M., Ramírez-Hernández, A. \& Micó, E. (2017) How does the replacement of native forest by exotic forest plantations affect the diversity, abundance and trophic structure of saproxylic beetle assemblages? Forest Ecology and Management, 405, 246-256.

Fraser, S.M. \& Lawton, J.H. (2008) Host range expansion by British moths onto introduced conifers. Ecological Entomology, 19, 127-137.

Gange, A.C., Gange, E.G., Mohammed, A.B. \& Boddy, L. (2011) Host shifts in fungi caused by climate change? Fungal Ecology, 4, 184-190.

Gillmann, M., Cailleret, M., Boivin, T., Nageleisen, L.-M. \& Davi, H. (2014) Individual vulnerability factors of Silver fir (Abies alba Mill.) to parasitism by two contrasting biotic agents: mistletoe (Viscum album L. ssp. abietis) and bark beetles (Coleoptera: Curculionidae Scolytinae) during a decline process. Annals of Forest Science, 71(6), 659-673.

Gossner, M. \& Ammer, U. (2006) The effects of Douglas-fir on treespecific arthropod communities in mixed species stands with European beech and Norway spruce. European Journal of Forest Research, 125, 221-235.
Gossner, M.M., Chao, A., Bailey, R.I. \& Prinzing, A. (2009) Native fauna on exotic trees: phylogenetic conservatism and geographic contingency in two lineages of phytophages on two lineages of trees. The American Naturalist, 173, 599-614.

Hartley, M.K., Rogers, W.E. \& Siemann, E. (2010) Comparisons of arthropod assemblages on an invasive and native trees: abundance, diversity and damage. Arthropod Plant Interactions, 4, 237-245.

Heilmann-Clausen, J. \& Læssøe, T. (2012) On species richness estimates, climate change and host shifts in wood-inhabiting fungi. Fungal Ecology, 5(5), 641-646.

Kappes, H. \& Topp, W. (2004) Emergence of Coleoptera from deadwood in a managed broadleaved forest in central Europe. Biodiversity and Conservation, 13, 1905-1924.

Kostanjsek, F., Sebek, P., Baranova, B., Seric Jelaska, L., Riedl, V. \& Cizek, L. (2018) Size matters! Habitat preferences of the wrinkled bark beetle, Rhysodes sulcatus, the relict species of European primeval forests. Insect Conservation and Diversity, 11, 545-553.

Lachat, T., Peveling, R., Attignon, S., Goergen, G., Sinsin, B. \& Nagel, P. (2007) Saproxylic beetle assemblages on native and exotic snags in a West African tropical forest. African Entomology, 15, 13-24.

Laliberté, E. \& Legendre, P. (2010) A distance-based framework for measuring functional diversity from multiple traits. Ecology, 91, 299-305.

Lassauce, A., Lieutier, F. \& Bouget, C. (2012) Woodfuel harvesting and biodiversity conservation in temperate forests. Effects of logging residue characteristics on saproxylic beetle assemblages. Biological Conservation, 147(1), 204-212.

Lindelöw, Å. \& Björkman, C. (2001) Insects on lodgepole pine in Sweden - current knowledge and potential risks. Forest Ecology and Management, 141(1-2), 107-116.

Lombardero, M.J., Alonso-Rodríguez, M. \& Roca-Posada, E.P. (2012) Tree insects and pathogens display opposite tendencies to attack native vs. non-native pines. Forest Ecology and Management, 281, 121-129.

Mansfield, S., McNeill, M.R., Aalders, L.T., Bell, N.L., Kean, J.M., Barratt, B.I.P., Boyd-Wilson, K. \& Teulon, D.A.J. (2019) The value of sentinel plants for risk assessment and surveillance to support biosecurity. NeoBiota, 48, 1-24.

McKinney, M.L. \& Lockwood, J.L. (1999) Biotic homogenization: a few winners replacing many losers in the next mass extinction. Trends in Ecology and Evolution, 14(11), 450-453.

Mori, A.S., Lertzman, K.P. \& Gustafsson, L. (2017) Biodiversity and ecosystem services in forest ecosystems: a research agenda for applied forest ecology. Journal of Applied Ecology, 54, 12-27.

Müller, J., Wende, B., Strob, C., Eugster, M., Gallenberger, I., Floren, A., Steffan-Dewenter, I., Linsenmair, K.E., Weisser, W.W., \& Gossner, M.M. (2015) Forest management and regional tree composition drive the host preference of saproxylic beetle communities. Journal of Applied Ecology, 52, 753-762.

Neuvonen, S. \& Niemela, P. (1981) Species richness of Macrolepidoptera on Finnish deciduous trees and shrubs. Oecologia, 51, 364-370.

Nittérus, K., Gunnarsson, B. \& Axelsson, E. (2004) Insects reared from logging residue on clear-cuts. Entomologica Fennica, 15, 53-61.

R Core Team. (2018) R: A Language and Environment for Statistical Computing, v3.5.1., Vienna, Austria. Available at: https://www.Rproject.org/.

Roques, A., Auger-Rozenberg, M.A. \& Boivin, S. (2006) A lack of native congeners may limit colonization of introduced conifers by indigenous insects in Europe. Canadian Journal in Forest Research, 36, 299-313.

Schmid, M., Pautasso, M. \& Holdenrieder, O. (2014) Ecological consequences of Douglas fir (Pseudotsuga menziesii) cultivation in Europe. European Journal of Forest Research, 133(1), 13-29.

Smart, S.M., Thompson, K., Marrs, R.H., Le Duc, M.G., Maskell, L. C. \& Firbank, L.G. (2006) Biotic homogenization and changes in 
species diversity across human-modified ecosystems. Proceedings of the Royal Society of London Series B Biological Sciences, 273 (1601), 2659-2665.

Stokland, J.N., Siitonen, J. \& Jonsson, B.G. (2012) Biodiversity in DeadWood. Cambridge University Press, Cambridge.

Thuillier, W., Lavorel, S., Araujo, M.B., Sykes, M.T. \& Prentice, I.C. (2005) Climate change threats to plant diversity in Europe. Proceedings of the National Academy of Sciences, 102(23), 8245-8250.

Tschopp, T., Holderegger, R. \& Bollmann, K. (2015) Auswirkungen der Douglasie auf die Waldbiodiversität. Schweizerische Zeitschrift für Forstwesen, 166(1), 9-15.
Ulyshen, M.D., Pawson, S.M., Branco, M.P., Van Horn, S.J., Hoebeke, E.R. \& Gossner, M.M. (2018) Chapter 23: utilization of non-native wood by saproxylic insects. Saproxylic Insects: Diversity, Ecology and Conservation. Zoological Monographs(ed. by M. Ulyshen), Vol. 1, pp. p. 797-834. Springer, Cham.

Zumr, V. (1992) Attractiveness of introduced conifers to xylophagous beetles and their acceptance. Journal of Applied Entomology, 113, 233-238.

Accepted 18 June 2020

Editor: Raphael Didham; Associate Editor: Jörg Müller 


\section{APPENDIX}

Table A1. Number of empty emergence bags per plot ( $n=40$ plots) across the sampling design for four paired tree species. Possible values for the empty bags are 0,1 or 2 . Variations in empty bag metrics related to tree species ( $P$-value based on likelihood ratio tests comparing null models and generalised (Poisson) linear mixed models): conifer-douglas fir mean $=0.80 \pm \mathrm{se} 0.15$, silver fir mean $=0.55 \pm \mathrm{se} 0.15$ (pval $=0.33 \mathrm{~ns}$ ); deciduous-beech mean $=0.35$ $\pm \mathrm{se} 0.13$, oak mean $=0.30 \pm \mathrm{se} 0.12(\mathrm{pvam}=0.78 \mathrm{~ns})$.

\begin{tabular}{|c|c|c|c|c|}
\hline Tree species group & Tree species & Region & Plot & $\mathrm{Nb}$ of empty bags \\
\hline deciduous & oak & baronnies1 & 1BARHE & 0 \\
\hline deciduous & oak & baronnies1 & 1HECHE & 0 \\
\hline deciduous & oak & baronnies1 & 2BARHE & 0 \\
\hline deciduous & oak & baronnies1 & 2HECHE & 1 \\
\hline deciduous & oak & baronnies1 & 3BARHE & 0 \\
\hline deciduous & oak & baronnies1 & 3HECHE & 0 \\
\hline deciduous & oak & baronnies1 & 4BARHE & 0 \\
\hline deciduous & oak & baronnies1 & 4HECHE & 2 \\
\hline deciduous & oak & baronnies1 & 5HECHE & 0 \\
\hline deciduous & oak & baronnies1 & 6HECHE & 1 \\
\hline deciduous & oak & normandie & 108EAWY & 0 \\
\hline deciduous & oak & normandie & 143EAWY & 0 \\
\hline deciduous & oak & normandie & 181EAWY & 1 \\
\hline deciduous & oak & normandie & 256EAWY & 0 \\
\hline deciduous & oak & normandie & 285EAWY & 0 \\
\hline deciduous & oak & normandie & 29EAWY & 0 \\
\hline deciduous & oak & normandie & 354EAWY & 0 \\
\hline deciduous & oak & normandie & 458EAWY & 0 \\
\hline deciduous & oak & normandie & 54EAWY & 0 \\
\hline deciduous & oak & normandie & 88EAWY & 1 \\
\hline conifer & douglas & baronnies2 & 1BANSA & 2 \\
\hline conifer & douglas & baronnies2 & 1BARSA & 2 \\
\hline conifer & douglas & baronnies2 & 1HECSA & 1 \\
\hline conifer & douglas & baronnies2 & 2BANSA & 1 \\
\hline conifer & douglas & baronnies2 & 2HECSA & 1 \\
\hline conifer & douglas & baronnies2 & 3BANSA & 1 \\
\hline conifer & douglas & baronnies2 & 3HECSA & 0 \\
\hline conifer & douglas & baronnies2 & 4HECSA & 2 \\
\hline conifer & douglas & baronnies2 & 5HECSA & 1 \\
\hline conifer & douglas & baronnies2 & 6HECSA & 0 \\
\hline conifer & douglas & sault & $10 \mathrm{COM}$ & 1 \\
\hline conifer & douglas & sault & $1 \mathrm{COM}$ & 1 \\
\hline conifer & douglas & sault & $2 \mathrm{COM}$ & 0 \\
\hline conifer & douglas & sault & $3 \mathrm{COM}$ & 0 \\
\hline conifer & douglas & sault & $4 \mathrm{COM}$ & 0 \\
\hline conifer & douglas & sault & $5 \mathrm{COM}$ & 1 \\
\hline conifer & douglas & sault & $6 \mathrm{COM}$ & 1 \\
\hline conifer & douglas & sault & $7 \mathrm{COM}$ & 0 \\
\hline conifer & douglas & sault & $8 \mathrm{COM}$ & 0 \\
\hline conifer & douglas & sault & $9 \mathrm{COM}$ & 1 \\
\hline deciduous & beech & baronnies1 & 1BARHE & 0 \\
\hline deciduous & beech & baronnies1 & $1 \mathrm{HECHE}$ & 0 \\
\hline deciduous & beech & baronnies 1 & 2BARHE & 0 \\
\hline deciduous & beech & baronnies 1 & 2HECHE & 0 \\
\hline deciduous & beech & baronnies1 & 3BARHE & 0 \\
\hline deciduous & beech & baronnies 1 & 3HECHE & 0 \\
\hline deciduous & beech & baronnies1 & 4BARHE & 0 \\
\hline deciduous & beech & baronnies1 & 4HECHE & 2 \\
\hline deciduous & beech & baronnies 1 & 5HECHE & 1 \\
\hline deciduous & beech & baronnies1 & 6HECHE & 1 \\
\hline
\end{tabular}


12 Christophe Bouget, Antoine Brin and Laurent Larrieu

Table A1. (continued)

\begin{tabular}{|c|c|c|c|c|}
\hline Tree species group & Tree species & Region & Plot & $\mathrm{Nb}$ of empty bags \\
\hline deciduous & beech & normandie & 108EAWY & 0 \\
\hline deciduous & beech & normandie & 143EAWY & 1 \\
\hline deciduous & beech & normandie & 181EAWY & 0 \\
\hline deciduous & beech & normandie & 256EAWY & 1 \\
\hline deciduous & beech & normandie & 285EAWY & 0 \\
\hline deciduous & beech & normandie & 29EAWY & 0 \\
\hline deciduous & beech & normandie & 354EAWY & 1 \\
\hline deciduous & beech & normandie & 458EAWY & 0 \\
\hline deciduous & beech & normandie & 54EAWY & 0 \\
\hline deciduous & beech & normandie & 88EAWY & 0 \\
\hline conifer & silver fir & baronnies2 & 1BANSA & 1 \\
\hline conifer & silver fir & baronnies2 & 1BARSA & 1 \\
\hline conifer & silver fir & baronnies2 & 1HECSA & 0 \\
\hline conifer & silver fir & baronnies2 & 2BANSA & 2 \\
\hline conifer & silver fir & baronnies2 & 2HECSA & 0 \\
\hline conifer & silver fir & baronnies2 & 3BANSA & 0 \\
\hline conifer & silver fir & baronnies2 & 3HECSA & 1 \\
\hline conifer & silver fir & baronnies2 & 4HECSA & 1 \\
\hline conifer & silver fir & baronnies2 & 5HECSA & 1 \\
\hline conifer & silver fir & baronnies2 & 6HECSA & 1 \\
\hline conifer & silver fir & sault & 10COM & 0 \\
\hline conifer & silver fir & sault & $1 \mathrm{COM}$ & 0 \\
\hline conifer & silver fir & sault & $2 \mathrm{COM}$ & 2 \\
\hline conifer & silver fir & sault & $3 \mathrm{COM}$ & 1 \\
\hline conifer & silver fir & sault & $4 \mathrm{COM}$ & 0 \\
\hline conifer & silver fir & sault & $5 \mathrm{COM}$ & 0 \\
\hline conifer & silver fir & sault & $6 \mathrm{COM}$ & 0 \\
\hline conifer & silver fir & sault & $7 \mathrm{COM}$ & 0 \\
\hline conifer & silver fir & sault & $8 \mathrm{COM}$ & 0 \\
\hline conifer & silver fir & sault & $9 \mathrm{COM}$ & 0 \\
\hline
\end{tabular}


Table A2. List of species and related ecological traits: host tree preference, feeding guild $(\mathrm{Myc}=$ Mycetophagous, $\mathrm{Xyl}=\mathrm{Xylophagous,} \mathrm{Sxy}=\mathrm{Saproxy}-$ lophagous, Zoo = zoophagous), rarity group, ab.decid (cumulative number of individuals in deciduous deadwood), ab.conif (cumulative number of individuals in conifer deadwood). Host tree preference was encoded with an index value: 1 (oligophagous or oak specialists associated with a few deciduous tree species at most), 2 (associated with deciduous tree species in general), 3 (polyphagous generalists associated to both conifer and decidous tree species), 4 (associated with conifer tree species in general), and 5 (oligophagous or fir specialists associated with a few conifer tree species at most).

\begin{tabular}{|c|c|c|c|c|c|c|c|c|c|}
\hline Species & Family & Dataset & $\begin{array}{l}\text { Host tree } \\
\text { preference }\end{array}$ & $\begin{array}{l}\text { Feeding } \\
\text { guild }\end{array}$ & $\begin{array}{l}\text { Rarity } \\
\text { group }\end{array}$ & $\begin{array}{l}\text { ab. } \\
\text { oak }\end{array}$ & $\begin{array}{l}\text { ab. } \\
\text { beech }\end{array}$ & $\begin{array}{c}\text { ab. } \\
\text { douglas }\end{array}$ & $\begin{array}{l}\text { ab. } \\
\text { abies }\end{array}$ \\
\hline $\begin{array}{l}\text { Acalles micros Dieckmann, } \\
1982\end{array}$ & CURCULIONIDAE & deciduous & 2 & Xyl & common & 3 & 2 & 0 & 0 \\
\hline $\begin{array}{l}\text { Acalles misellus Boheman, } \\
1844\end{array}$ & CURCULIONIDAE & deciduous & 3 & Xyl & common & 1 & 0 & 0 & 0 \\
\hline $\begin{array}{l}\text { Anaspis maculata Geoffroy in } \\
\text { Fourcroy, } 1785\end{array}$ & SCRAPTIIDAE & conifer & 2 & Sxy & common & 0 & 0 & 0 & 1 \\
\hline $\begin{array}{l}\text { Anisandrus dispar (Fabricius, } \\
\text { 1792) }\end{array}$ & CURCULIONIDAE & deciduous & 3 & Xyl & common & 49 & 14 & 0 & 0 \\
\hline $\begin{array}{l}\text { Arthrolips fasciata (Erichson, } \\
\text { 1842) }\end{array}$ & CORYLOPHIDAE & deciduous,conifer & 2 & Sap & common & 2 & 0 & 1 & 1 \\
\hline Atomaria sp. & CRYPTOPHAGIDAE & deciduous & 3 & Myc & common & 0 & 0 & 0 & 0 \\
\hline $\begin{array}{l}\text { Aulonothroscus brevicollis } \\
\text { (Bonvouloir, 1859) }\end{array}$ & THROSCIDAE & deciduous & 2 & Sxy & common & 1 & 0 & 0 & 0 \\
\hline Bryaxis curtisii (Leach, 1817) & STAPHYLINIDAE & deciduous & 3 & Zoo & common & 1 & 0 & 0 & 0 \\
\hline $\begin{array}{l}\text { Cartodere nodifer } \\
\text { (Westwood, 1839) }\end{array}$ & LATRIDIIDAE & $\begin{array}{l}\text { deciduous, } \\
\text { conifer }\end{array}$ & 2 & Myc & common & 0 & 4 & 2 & 1 \\
\hline $\begin{array}{l}\text { Cerylon fagi C. Brisout } \\
\text { de Barneville, } 1867\end{array}$ & CERYLONIDAE & deciduous & 2 & Myc & common & 2 & 0 & 0 & 0 \\
\hline $\begin{array}{l}\text { Cerylon histeroides } \\
\text { (Fabricius, 1792) }\end{array}$ & CERYLONIDAE & deciduous & 3 & Myc & common & 0 & 1 & 0 & 0 \\
\hline Corticarina sp. & LATRIDIIDAE & conifer & 3 & Myc & common & 0 & 0 & 0 & 0 \\
\hline $\begin{array}{l}\text { Cryphalus asperatus } \\
\text { (Gyllenhal, 1813) }\end{array}$ & CURCULIONIDAE & conifer & 4 & Xyl & common & 0 & 0 & 4 & 50 \\
\hline $\begin{array}{l}\text { Cryptolestes duplicatus } \\
\text { (Waltl, 1839) }\end{array}$ & LAEMOPHLOEIDAE & deciduous & 2 & Zoo & common & 3 & 0 & 0 & 0 \\
\hline Cryptophagus sp. & CRYPTOPHAGIDAE & $\begin{array}{l}\text { deciduous, } \\
\text { conifer }\end{array}$ & 3 & Myc & common & 0 & 0 & 0 & 0 \\
\hline $\begin{array}{l}\text { Dacne bipustulata (Thunberg, } \\
\text { 1781) }\end{array}$ & EROTYLIDAE & deciduous & 3 & Myc & common & 0 & 1 & 0 & 0 \\
\hline $\begin{array}{l}\text { Dasytes croceipes } \\
\text { Kiesenwetter, } 1866\end{array}$ & DASYTIDAE & conifer & 3 & Zoo & common & 0 & 0 & 0 & 1 \\
\hline $\begin{array}{l}\text { Diplocoelus fagi Guérin- } \\
\text { Méneville, } 1838\end{array}$ & BIPHYLLIDAE & deciduous & 1 & Myc & common & 9 & 16 & 0 & 0 \\
\hline $\begin{array}{l}\text { Dryocoetes autographus } \\
\text { (Ratzeburg, 1837) }\end{array}$ & CURCULIONIDAE & conifer & 4 & Xyl & common & 0 & 0 & 89 & 11 \\
\hline Epurea sp. & NITIDULIDAE & deciduous & 3 & Zoo & common & 0 & 0 & 0 & 0 \\
\hline $\begin{array}{l}\text { Eulagius filicornis (Reitter, } \\
\text { 1887) }\end{array}$ & MYCETOPHAGIDAE & deciduous & 1 & Myc & common & 1 & 0 & 0 & 0 \\
\hline $\begin{array}{l}\text { Hylastes angustatus (Herbst, } \\
1793 \text { ) }\end{array}$ & CURCULIONIDAE & conifer & 4 & Xyl & common & 0 & 0 & 1 & 0 \\
\hline $\begin{array}{l}\text { Hylesinus varius (Fabricius, } \\
\text { 1775) }\end{array}$ & CURCULIONIDAE & conifer & 2 & Xyl & common & 0 & 0 & 1 & 0 \\
\hline $\begin{array}{l}\text { Kyklioacalles pyrenaeus } \\
\text { (Boheman, 1844) }\end{array}$ & CURCULIONIDAE & conifer & 3 & $\mathrm{Xyl}$ & rare & 0 & 0 & 4 & 2 \\
\hline $\begin{array}{l}\text { Laemophloeus kraussi } \\
\text { Ganglbauer, } 1897\end{array}$ & LAEMOPHLOEIDAE & deciduous & 2 & Zoo & rare & 0 & 3 & 0 & 0 \\
\hline $\begin{array}{l}\text { Leiodes flavicornis (Brisout } \\
\text { de Barneville, 1884) }\end{array}$ & LEIODIDAE & conifer & 2 & Myc & common & 0 & 0 & 1 & 0 \\
\hline $\begin{array}{l}\text { Leiopus nebulosus (Linnaeus, } \\
1758 \text { ) }\end{array}$ & CERAMBYCIDAE & deciduous & 2 & Xyl & common & 1 & 0 & 0 & 0 \\
\hline $\begin{array}{l}\text { Lissodema lituratum (A. } \\
\text { Costa, 1847) }\end{array}$ & SALPINGIDAE & conifer & 2 & Zoo & common & 0 & 0 & 1 & 0 \\
\hline
\end{tabular}


Table A2. (continued)

\begin{tabular}{|c|c|c|c|c|c|c|c|c|c|}
\hline Species & Family & Dataset & $\begin{array}{l}\text { Host tree } \\
\text { preference }\end{array}$ & $\begin{array}{l}\text { Feeding } \\
\text { guild }\end{array}$ & $\begin{array}{l}\text { Rarity } \\
\text { group }\end{array}$ & $\begin{array}{l}\text { ab. } \\
\text { oak }\end{array}$ & $\begin{array}{l}\text { ab. } \\
\text { beech }\end{array}$ & $\begin{array}{c}\text { ab. } \\
\text { douglas }\end{array}$ & $\begin{array}{l}\text { ab. } \\
\text { abies }\end{array}$ \\
\hline $\begin{array}{l}\text { Litargus connexus (Geoffroy, } \\
1785 \text { ) }\end{array}$ & MYCETOPHAGIDAE & deciduous & 3 & Myc & common & 1 & 0 & 0 & 0 \\
\hline $\begin{array}{l}\text { Palaeoacalles navieresi } \\
\text { (Boheman, 1837) }\end{array}$ & CURCULIONIDAE & conifer & 1 & Xyl & common & 0 & 0 & 0 & 8 \\
\hline Pissodes piceae (Illiger, 1807) & CURCULIONIDAE & conifer & 5 & Xyl & common & 0 & 0 & 0 & 20 \\
\hline $\begin{array}{l}\text { Pityokteines curvidens } \\
\text { (Germar, 1824) }\end{array}$ & CURCULIONIDAE & conifer & 5 & Xyl & common & 0 & 0 & 0 & 3 \\
\hline $\begin{array}{l}\text { Placonotus testaceus } \\
\text { (Fabricius, 1787) }\end{array}$ & LAEMOPHLOEIDAE & conifer & 3 & Zoo & common & 0 & 0 & 0 & 7 \\
\hline $\begin{array}{l}\text { Ptilinus fuscus Geoffroy in } \\
\text { Fourcroy, } 1785\end{array}$ & PTINIDAE & deciduous & 2 & Sxy & common & 1 & 0 & 0 & 0 \\
\hline $\begin{array}{l}\text { Ptinomorphus imperialis } \\
\text { (Linnaeus, 1767) }\end{array}$ & PTINIDAE & deciduous & 2 & Sxy & common & 0 & 2 & 0 & 0 \\
\hline $\begin{array}{l}\text { Pyrrhidium sanguineum } \\
\text { (Linnaeus, 1758) }\end{array}$ & CERAMBYCIDAE & deciduous & 2 & Xyl & common & 3 & 0 & 0 & 0 \\
\hline $\begin{array}{l}\text { Rhizophagus bipustulatus } \\
\text { (Fabricius, 1792) }\end{array}$ & MONOTOMIDAE & deciduous,conifer & 3 & Zoo & common & 25 & 7 & 9 & 34 \\
\hline $\begin{array}{l}\text { Rhizophagus dispar (Paykull, } \\
\text { 1800) }\end{array}$ & MONOTOMIDAE & conifer & 3 & Zoo & common & 0 & 0 & 4 & 7 \\
\hline $\begin{array}{l}\text { Rhizophagus nitidulus } \\
\text { (Fabricius, 1798) }\end{array}$ & MONOTOMIDAE & deciduous & 3 & Zoo & common & 3 & 2 & 0 & 0 \\
\hline $\begin{array}{l}\text { Rhyncolus ater (Linnaeus, } \\
1758 \text { ) }\end{array}$ & CURCULIONIDAE & conifer & 4 & Sxy & common & 0 & 0 & 3 & 0 \\
\hline $\begin{array}{l}\text { Salpingus planirostris } \\
\text { (Fabricius, 1787) }\end{array}$ & SALPINGIDAE & deciduous & 2 & Zoo & common & 1 & 0 & 0 & 0 \\
\hline $\begin{array}{l}\text { Salpingus ruficollis (Linnaeus, } \\
1760 \text { ) }\end{array}$ & SALPINGIDAE & deciduous & 3 & Zoo & common & 1 & 0 & 0 & 0 \\
\hline $\begin{array}{l}\text { Scaphidium quadrimaculatum } \\
\text { Olivier, } 1790\end{array}$ & STAPHYLINIDAE & conifer & 3 & Myc & common & 0 & 0 & 1 & 0 \\
\hline $\begin{array}{l}\text { Scolytus intricatus } \\
\text { (Ratzeburg, 1837) }\end{array}$ & CURCULIONIDAE & deciduous & 2 & Xyl & common & 5 & 0 & 0 & 0 \\
\hline $\begin{array}{l}\text { Stenichnus scutellaris (P.W.J. } \\
\text { Müller \& Kunze, 1822) }\end{array}$ & STAPHYLINIDAE & conifer & 2 & Zoo & common & 0 & 0 & 1 & 0 \\
\hline Tachyporus sp. & STAPHYLINIDAE & conifer & 3 & Zoo & common & 0 & 0 & 0 & 0 \\
\hline $\begin{array}{l}\text { Trachodes hispidus } \\
\text { (Linnaeus, 1758) }\end{array}$ & CURCULIONIDAE & deciduous & 3 & Xyl & common & 0 & 1 & 0 & 0 \\
\hline $\begin{array}{c}\text { Trotomma pubescens } \\
\text { Kiesenwetter, } 1851\end{array}$ & SCRAPTIIDAE & conifer & 3 & Sxy & common & 0 & 0 & 1 & 0 \\
\hline $\begin{array}{l}\text { Trypodendron signatum } \\
\text { (Fabricius, 1792) }\end{array}$ & CURCULIONIDAE & deciduous & 2 & Xyl & common & 5 & 2 & 0 & 0 \\
\hline $\begin{array}{l}\text { Uleiota planatus (Linnaeus, } \\
1760 \text { ) }\end{array}$ & SILVANIDAE & conifer & 3 & Zoo & common & 0 & 0 & 1 & 0 \\
\hline $\begin{array}{l}\text { Xyleborinus saxesenii } \\
\text { (Ratzeburg, 1837) }\end{array}$ & CURCULIONIDAE & deciduous,conifer & 3 & Xyl & common & 159 & 69 & 7 & 2 \\
\hline $\begin{array}{l}\text { Xyleborus monographus } \\
\text { (Fabricius, 1792) }\end{array}$ & CURCULIONIDAE & deciduous & 1 & Xyl & common & 4 & 1 & 0 & 0 \\
\hline $\begin{array}{l}\text { Xylosandrus germanus } \\
\text { (Blandford, 1894) }\end{array}$ & CURCULIONIDAE & deciduous & 3 & Xyl & common & 913 & 245 & 0 & 0 \\
\hline
\end{tabular}




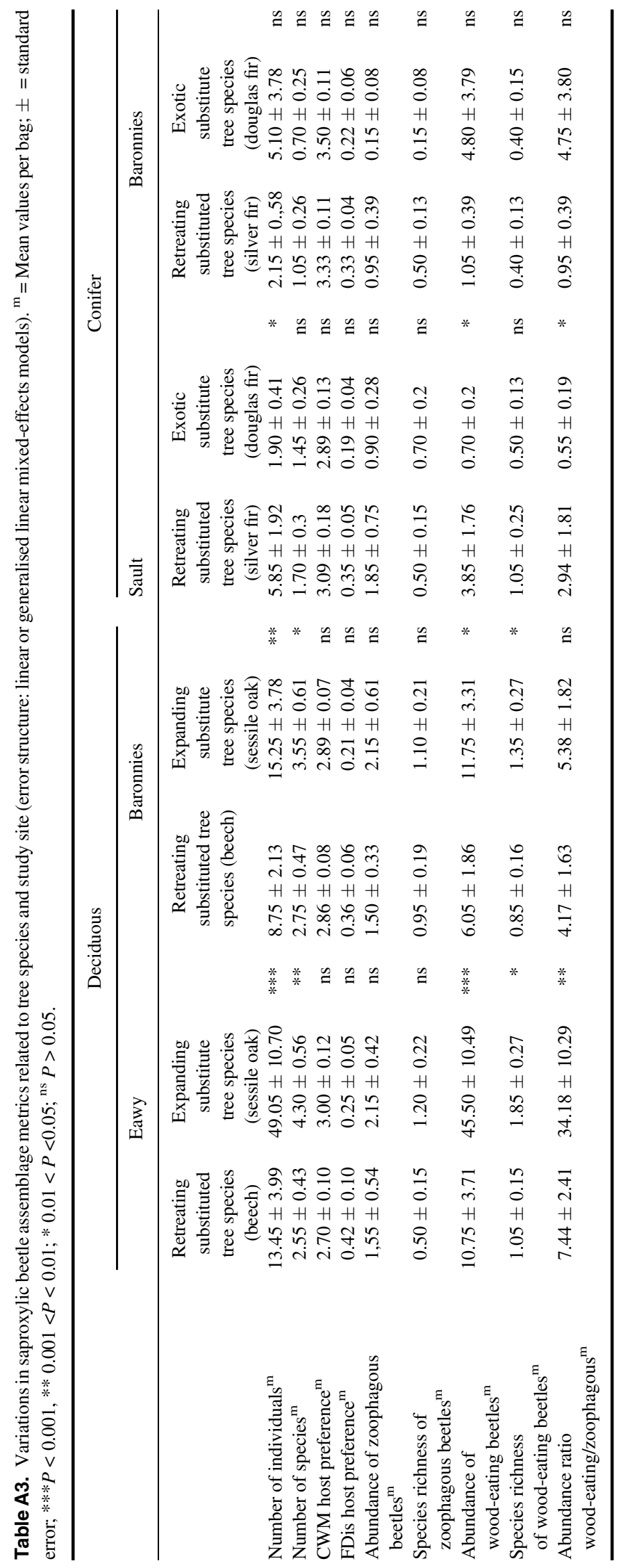

(C) 2020 The Royal Entomological Society, Insect Conservation and Diversity, doi: 10.1111/icad.12434 